\title{
DISKRIMINASI NEGARA TERHADAP AGAMA DI INDONESIA \\ Studi atas Persoalan Posisi Hukum Towani Tolotang Pasca Pengakuan Agama Resmi
}

\author{
Hasse J. \\ Program Studi Agama dan Lintas Budaya \\ Sekolah Pascasarjana Universitas Gadjah Mada \\ Email: praktisi_99@yahoo.com \\ Bernard Adeney Risakotta \\ Universitas Kristen Duta Wacana \\ Zainal Abidin Bagir \\ Program Studi Agama dan Lintas Budaya Sekolah Pascasarjana \\ Universitas Gadjah Mada
}

\begin{abstract}
This paper aims to analyze the legal position of Towani Tolotang in the case of restrictions on religion in Indonesia. This paper is based on research toward the Towani Tolotang community in the Sidenreng Rappang Regency. Towani Tolotang is a local religion that continues to survive despite attempts to disband its followers, efforts which come not only from groups which disagree with the religion's existence, but is also from the state. The discrimination experienced by followers of Towani Tolotang comes from two directions: first, from the public in the form of assumptions which denounce them, and second, from the government through a variety of regulations which limit the space for followers of Towani Tolotang to develop its teachings.
\end{abstract}

Keywords: Towani Tolotang, Discrimination, Religion and State Relation

\begin{abstract}
ABSTRAK
Tulisan ini bertujuan untuk mengetahui posisi hukum Towani Tolotang setelah adanya pembatasan mengenai agama di Indonesia. Tulisan ini didasarkan pada penelitian pada agama Towani Tolotang di Kabupaten Sidenreng Rappang. Towani Tolotang merupakan agama lokal yang hingga kini masih bertahan di tengah berbagai upaya pemusnahan terhadap mereka. Upaya tersebut dilakukan bukan hanya dari kelompok atau kalangan yang tidak setuju dengan kehadiran agama-agama non-resmi, tetapi juga terjadi dari adanya regulasi negara mengenai agama-agama yang diakui. Diskriminasi yang dialami oleh Towani Tolotang datang dari dua arah. Pertama, dari masyarakat yang berupa anggapan-anggapan yang mencela mereka, dan kedua adalah format diskriminasi yang dihadirkan oleh pemerintah melalui berbagai macam regulasi yang membatasi ruang gerak Towani Tolotang dalam mengembangkan ajaranajarannya.
\end{abstract}

Kata Kunci: Towani Tolotang, Diskriminasi, Relasi Agama dan Negara 


\section{PENGANTAR}

Negara secara formal hanya mengakui enam agama di Indonesia yakni Islam, Kristen, Katolik, Hindu, Budha, dan Konghucu (Qoyim, 2004: 28). Dengan demikian, hanya agama-agama tersebut yang memiliki representasi di Kementerian Agama baik di tingkat pusat maupun daerah. Agama-agama yang mendapat pengakuan memiliki ruang untuk mengekspresikan ajaran-ajaran melalui praktik-praktik keagamaan seperti ibadah dan perayaan-perayaan. Agama-agama tersebut memiliki struktur organisasi yang lengkap yang menunjang keberlangsungan pelaksanaan dan penyebaran ajaran. Dengan struktur organisasi seperti ini, agama-agama tersebut dimanjakan dengan fasilitas-fasilitas penunjang eksistensi di masa datang.

Di samping Kementerian Agama, keberadaan beberapa organisasi keagamaan seperti Majelis Ulama Indonesia (MUI), Persekutuan Gereja-gereja Indonesia (PGI), Konferensi Wali Gereja Indonesia (KWGI), Parisada Hindu Dharma Indonesia (PHDI), WALUBI, dan Majelis Tinggi Agama Konghucu Indonesia (MATAKIN) juga membuktikan keberpihakan negara terhadap agamaagama tertentu, khususnya keenam agama tadi. Organisasi-organisasi tersebut mencerminkan pengakuan negara terhadap agama yang diwakili masing-masing organisasi. Keberadaan wadah pendukung yang hanya terbatas dimiliki oleh enam agama menegaskan keterbatasan paham pluralitas yang dianut oleh negara (Kholiludin, 2009: 16). Pluralitas hanya dipahami sebatas agama resmi saja dan mengesampingkan keberadaan agama-agama lokal yang hadir bahkan lebih awal dari agama-agama besar saat ini.

Agama-agama lokal merupakan agama yang dianut oleh masyarakat Indonesia jauh sebelum agama-agama 'impor' dikenal. Agama ini hadir di setiap kelompok masyarakat yang menampilkan wajah yang berbeda dengan apa yang dianut di tempattempat lain. Di beberapa tempat seperti Jawa meskipun arus Islam sangat kuat, teta- pi sisa-sisa agama orang terdahulu masih ada seperti Tengger, Samin, dan lain-lain (Nurudin, 2003; Rosyid, 2010). Di Sumatera juga demikian, agama Permalim masih dapat ditemukan meskipun penganutnya sangat sedikit. Di Kalimantan, Kaharingan masih dapat ditemukan di beberapa tempat khususnya di pedalaman. Di Sulawesi, eksistensi Towani Tolotang, Ammatoa, Aluk Todolo, dan lain-lain (Hasse J, 2008; Idaman, 2005; Ma'arif, 2003) menunjukkan masih adanya sisa-sisa agama pra-Islam yang dianut di daerah ini. Di Maluku, Nusa Tenggara, dan Papua juga demikian, agama-agama lokal masih banyak ditemukan meskipun terbatas hanya di daerah-daerah tertentu yang sangat terpencil. Hal ini menegaskan bahwa hingga saat ini, agama-agama lokal ada namun dalam kondisi yang serba terbatas bahkan terancam keberadaannya.

Pengakuan negara terhadap keberadaan agama yang hanya terbatas pada enam seperti uraian di atas, menciptakan persoalan krusial dalam pengelolaan agama di Indonesia. Salah satu persoalan yang timbul adalah lahirnya dikotomi antara agama yang 'diakui' dan yang 'tidak diakui', mayoritas dan minoritas, agama global dan agama lokal, primitif dan modern, dan lain sebagainya. Keberadaan agama-agama (yang diakui) selama ini menjadi 'lawan' agamaagama lokal. Agama-agama yang diakui mendapat kemudahan-kemudahan, sementara agama-agama lokal selalu diposisikan sebagai agama yang tertindas, termarjinalkan, dan terhakimi yang tidak memiliki ruang ekspresi keagamaan yang proporsional. Agama-agama lokal diposisikan sebagai sasaran 'pencerahan' melalui dakwah dan gerakan-gerakan penyadaran lainnya.

Mengenai agama lokal khususnya di Indonesia juga telah banyak mendapat perhatian para peneliti. Nurudin (2003) menguraikan tentang potret kearifan hidup masyarakat Samin dan Tengger. Ia melihat bagaimana 'agama' Samin dan Tengger dipakai sebagai pedoman hidup dan dijadikan kaidah dalam menjalani kehidupan. Bagi anak-anak muda Samin, mereka cen- 
derung mulai meninggalkan ke-Samin-annya. Bahkan, di antara mereka ada yang malu disebut sebagai keturunan Samin. Mereka lebih suka disebut santri daripada keturunan Samin. Sebaliknya, dalam masyarakat Tengger, mereka masih memegang kepatuhan terhadap tradisi leluhur yang diwarisinya secara turun-temurun. Mereka mempertahankan ajaran hingga saat ini. Nurudin dalam konteks ini melihat agama lokal sebagai sebuah pedoman hidup seperti halnya pemahaman penganut agama lain terhadap agamanya. Fokus tulisan ini adalah terdapat pada bagaimana agama lokal diamalkan oleh para penganutnya.

Mattulada (1982) menyinggung perkembangan agama-agama lokal di Sulawesi Selatan di mana agama-agama lokal yang dikenal di kalangan orang Bugis merupakan agama leluhur yang masih dipercayai dan dianut oleh komunitas tertentu. Mereka menganut agama tersebut disebabkan oleh faktor keturunan. Ajaran diwariskan dari leluhur kepada generasi setelahnya. Mattulada hanya sebatas memperkenalkan bentuk-bentuk religi yang dikenal di kalangan masyarakat Bugis tanpa mengurai secara komprehensif persoalan yang dihadapi oleh agama yang masih dianut oleh beberapa kelompok. Dalam tulisan lain, Mattulada juga menguraikan secara singkat religi atau agama masyarakat Sulawesi Selatan sebelum kedatangan Islam di mana masyarakat Sulawesi Selatan sebelum memeluk Islam masih menjalankan kepercayaan-kepercayaan yang dikenal secara turun-temurun dari leluhur. Di antara kepercayaan yang dianut adalah kepercayaan orang Tolotang yang berpegang teguh pada tradisi leluhur yang ia kelompokkan ke dalam agama animisme.

Martin Ramstedt (2004) memberikan gambaran yang lebih luas dan spesifik tentang keberadaan agama-agama lokal yang telah menjadi bagian agama Hindu di Indonesia. Ia menegaskan bahwa telah terjadi hinduisasi di beberapa tempat di Indonesia, termasuk di Sulawesi Selatan. Proses hin- duisasi tersebut dilakukan oleh negara yang mengkategorikan beberapa agama lokal sebagai Hindu. Towani Tolotang merupakan salah satu 'korban' kebijakan tersebut. Towani Tolotang dianggap memiliki banyak persamaan dengan ajaran Hindu sehingga dikategorikan sebagai Hindu. Secara struktural Towani Tolotang menganut Hindu, namun secara kultural masih tetap pada ajarannya. Demikian pula, beberapa agama lokal dimerger ke dalam agama Hindu karena formalisasi agama. Mereka harus memilih salah satu agama yang telah diakui oleh negara untuk menghindarkan diri dari stigma 'ateis'.

\section{PEMBAHASAN \\ Dinamika Kehidupan Sosial Ke- masyarakatan Towani Tolotang}

Di kalangan Towani Tolotang, soliditas dan solidaritas sangat dikedepankan. Hal ini dilihat pada pelaksanaan kegiatan baik yang bersifat keagamaan maupun kegiatan sosial kemasyarakatan. Dalam pelaksanaan ritual Sipulung misalnya, yang dilaksanakan sekali setahun, para penganut berbondongbondong ke tempat ritual dengan penuh semangat dan meninggalkan segala aktivitas yang lain. Tempat ritual ini tidak berlokasi di tengah perkampungan mereka, tetapi berada sekitar $8 \mathrm{~km}$ dari pusat pemukiman Towani Tolotang. Lokasi yang jauh dari pemukiman tidak menyurutkan semangat mereka untuk mengikuti ritual. Ini menegaskan bahwa pada satu sisi, keyakinan mereka terhadap ajaran masih kuat dan pada sisi lain soliditas kelompok juga masih terjaga.

Solidaritas Towani Tolotang berwujud kesadaran mereka untuk saling membantu dalam pelakasanaan atau perayaan hajatan. Pada pelaksanaan perkawinan salah satu pemuka Towani Tolotang (La Unga Setti, 29 September 2010) misalnya, mereka telah datang jauh hari sebelum pelaksanaan hajatan dan membantu mendirikan tempat di samping rumah. Pada perayaan hajatan seperti perkawinan, Towani Tolotang biasanya membuat sarapo, merupakan tambah- 
an di samping rumah yang sejajar dengan rumah Induk, yang disambung dengan rumah induk sebagai tempat para tamu. Pada perayaan perkawinan tersebut, penganut Towani Tolotang dengan penuh semangat berada di tempat tanpa diundang untuk membantu. Pembuatan sarapo sendiri membutuhkan tenaga dan bahan yang tidak sedikit. Akan tetapi, mengingat rasa persaudaraan mereka sangat kental, maka pembuatan sarapo tersebut tidak memakan waktu yang lama karena dilakukan oleh banyak orang. Penganut yang datang tidak hanya dari lingkungan terdekat, tetapi juga berasal dari luar daerah mengingat yang melaksanakan hajatan adalah salah seorang pemuka Towani Tolotang.

Di kalangan muslim, yang hidup berdampingan dengan Towani Tolotang, mengakui kuatnya soliditas dan solidaritas Towani Tolotang. Salah seorang pemuka muslim mengatakan,

Towani Tolotang selalu bersatu dalam melaksanakan apapun, baik yang berhubungan dengan pelaksanaan upacara-upacara agama maupun yang lain. Mereka selalu saling membantu. Mereka tidak hanya membantu sesamanya tetapi juga dengan orang lain (Wawancara dengan Usman Suara (46), tanggal 23 Agustus 2008).

Keterlibatan Towani Tolotang dalam kegiatan sosial tidak hanya terbatas pada kegiatan kemasyarakatan yang bersifat umum, tetapi juga pada kegiatan yang menunjukkan identitas sebuah kelompok agama tertentu. Dalam pembangunan masjid misalnya, salah seorang dari mereka juga ikut membantu. Seperti yang dilakukan oleh La Gugu (50 tahun) yang telah menyelesaikan pemasangan atap masjid al Mujahidin BolaBulu. Menurutnya, panitia pembangunan masjid yang langsung menghubunginya. Lanjut dia, permintaan tersebut tidak berhubungan sama sekali dengan kapasitasnya sebagai penganut Towani Tolotang tetapi dalam hubungan yang bersifat professional yakni profesinya sebagai tukang kayu yang bisa memasang atap seperti yang sedang dibutuhkan oleh panitia pambangunan masjid.
Dalam kehidupan sosial yang lain, soliditas dan solidaritas Towani Tolotang dapat dilihat pada penyatuan sikap menghadapi berbagai persoalan. Merujuk pada masa lalu misalnya, ketika salah seorang Towani Tolotang meninggal yang kebetulan adalah putra $u w a^{\prime}$, sikap resisten terhadap 'dominasi Muslim' sangat jelas. Saat itu, pemerintah bersama-sama masyarakat muslim di Amparita tidak mengijinkan penguburan menurut Towani Tolotang. Mereka menghendaki penguburan secara Islam, padahal yang meninggal adalah penganut Towani Tolotang. Ketegangan pun tidak bisa dihindari bahkan konflik terbuka antara Towani Tololang dan muslim hampir terjadi karena kedua pihak tetap pada prinsip masingmasing. Towani Tolotang dengan tegas menentang penguburan secara Islam, artinya mereka sama sekali tidak mau tunduk terhadap keinginan tersebut.

Di kalangan masyarakat Sidenreng Rappang, saat ini bahkan telah tersimpan dalam ingatan mereka atas kesolidan internal Towani Tolotang. Di kalangan masyarakat telah terkonstruksi bahwa persatuan Towani Tolotang sangat kuat sehingga jika ingin melakukan konfrontasi dengan mereka sangat sulit. Pada persoalan konflik misalnya, pemuda muslim tidak ingin terlibat dengan pemuda Towani Tolotang karena dikhawatirkan akan terjadi konflik terbuka. Pemuka Towani Tolotang juga mengamini kondisi ini. Menurut Launga Setti, dari kecil, generasi Towani Tolotang memang telah ditanamkan sikap-sikap seperti itu (persatuan di internal kelompok) yang tidak hanya terbatas pada persoalan keagamaan, tetapi juga sosial kemasyarakatan. Ini menunjukkan bahwa, pihak luar pun (muslim) mengakui soliditas dan solidaritas internal Towani Tolotang. Hal yang lebih penting dari gambaran kondisi ini adalah adanya pengakuan pihak luar yang juga berdampak pada keberlangsungan hubungan antara Towani Tolotang dan muslim.

Hal di atas menegaskan dua poin penting yang terjadi saat ini di kalangan Towani Tolotang dalam hubungannya dengan dinamika pergaulan di internal mereka. Per- 
tama, soliditas di antara penganut tidak hanya berlangsung pada tataran yang bersifat ideologis atau pelaksanaan ajaran, tetapi juga pada tataran kehidupan sosial yang bersifat umum. Kedua, keterlibatan Towani Tolotang dalam kegiatan dan relasi sosial dengan masyarakat muslim menunjukkan adanya 'penerimaan' dari pihak lain terhadap kehadiran mereka. Hal tersebut memungkinkan pergaulan Towani Tolotang pada tataran sosial tidak mengalami hambatan yang mengakibatkan adanya resistensi dari kelompok lain dalam hal ini kelompok muslim yang hidup berdampingan dengan mereka.

\section{Harmonisasi dengan Kekuasaan: Politik, Ekonomi, dan Pendidikan}

Afiliasi Towani Tolotang ke dalam agama Hindu sebagai agama induk berdampak langsung pada relasinya dengan kekuasaan (negara). Membicarakan persoalan ini, sangat terkait pula dengan bagaimana hubungan agama secara umum dengan negara. Dalam tulisan ini, penulis akan menguraikan bagaimana bentuk-bentuk relasi agama dengan negara dan bagaimana Towani Tolotang menempatkan diri sebagai bagian dari sebuah agama yang diakui oleh negara. Secara struktural, Towani Tolotang adalah bagian integral agama Hindu. Ini berarti, segala urusan tidak bisa terlepas dari agama induknya. Dalam struktur organisasi PHDI, Towani Tolotang tercantum sebagai salah satu mazhab Hindu. Di Kabupaten Sidenreng Rappang sendiri terdapat pengurus PHDI kabupaten. Saat ini, ketua PHDI Kabupaten Sidenreng Rappang adalah Sunarto atau Wa Narto, salah seorang tokoh Towani Tolotang. Keterlibatan Wa Narto sebagai pengurus PHDI merupakan langkah penting untuk menghubungkan Towani Tolotang dengan kekuasaan.

Keterlibatan Towani Tolotang secara langsung dalam kepengurusan PHDI sangat berdampak pada posisi tawar 'politik' khususnya pada level lokal. Pada level politik lokal, Towani Tolotang yang menempati jumlah (kuantitas) terbesar kedua, memiliki posisi yang sangat strategis dalam setiap pelaksanaan pemilihan kepala daerah yang saat ini dilakukan secara langsung. Secara berturut-turut, salah seorang dari mereka duduk di DPRD Kabupaten. Bahkan, pada pemilihan 2009 lalu, terdapat dua kursi (La Panca dan Rukiyah merupakan dua orang berhasil duduk di kursi legislatif kabupaten Sidenreng Rappang periode 2009-2014) yang diduduki oleh Towani Tolotang. Pada setiap pemilu, beberapa orang dari kalangan Towani Tolotang maju sebagai calon anggota legislatif di Kabupaten Sidenrang Rappang.

Fakta di atas menunjukkan bahwa posisi Towani Tolotang di Sidenreng Rappang berbeda dengan dengan posisi beberapa komunitas agama lokal di tempat-tempat lain. Towani Tolotang sangat penting terkait dengan dinamika politik lokal yang terus terjadi. Ini dapat dinilai sebagai sesuatu yang wajar mengingat jumlah penganut Towani Tolotang sangat signifikan, misalnya untuk kepentingan pemilukada. Demikian pula, soliditas kelompok Towani Tolotang hingga saat ini masih terjaga. Keterlibatan Towani Tolotang dalam politik lokal di satu sisi menguntungkan, namun di sisi lain justru merugikan. Keuntungan yang dapat diperoleh dari keterlibatan tersebut adalah keberlangsungan eksistensi komunitas masih terjaga meskipun keberhasilan penganutnya menduduki kursi legislatif bukan atas nama komunitas tetapi keterwakilan partai yang mengusungnya. Di sisi lain, keberhasilan Towani Tolotang masuk dalam area politik praktis berdampak pada ancaman terbukanya kran 'konflik' internal. Figur yang selama ini maju dan mencalonkan diri merupakan figur yang berlatar-belakang keluarga 'elite' Towani Tolotang, bahkan dari kalangan elite sendiri. Pada tahun 2004, salah seorang elite Towani Tolotang, La Unga Setti, lolos sebagai anggota legislatif. Ia merupakan salah seorang tokoh penting Towani Tolotang. Ia adalah juru bicara Towani Tolotang, juru bicara komunitas. Keterlibatan elite atau keturunan elite seperti berpotensi melahirkan perpecahan karena setiap uwa atau 
uwatta memiliki basis massa sendiri. Massa masing-masing $u w a$ atau $u w a t t a$ tidak terkonsentrasi pada satu area saja tetapi tersebar di beberapa tempat.

Identifikasi jumlah massa (umat) setiap uwa atau uwatta dapat dilakukan dengan melihat seberapa besar orang yang melakukan mappenre' nanre (sebuah upacara siklus kehidupan Towani Tolotang). Setiap uwa atau uwatta memiliki pengikut. Pengikut setiap uwa atau uwatta dapat berupa umat yang berasal dari pengikut uwa terdahulu atau berasal dari penganut Towani Tolotang yang lain yang merasa sesuai dengan $u w a$ yang bersangkutan. Apabila orang tua $u w a$ sekarang adalah uwa, maka pengikutnya dilayani oleh anaknya yang saat ini menjadi uwa. Perpecahan pengikut bahka uwa dapat terjadi ketika orang tua meninggal dan meninggalkan beberapa generasi (anak) yang keseluruhannya menjadi uwa. Demikian pula sebaliknya, jika uwa tidak meninggalkan penerus atau tidak ada anak yang berkeinginan untuk mewarisi peran orang tua sebagai $u w a$.

Afiliasi ke dalam agama Hindu yang bersifat struktural telah mengubah kondisi Towani Tolotang pada bidang termasuk pendidikan. Saat ini, di beberapa sekolah di Sidenreng Rappang telah ada guru agama Hindu yang berasal dari Towani Tolotang. Di SMP 1 Amparita misalnya, guru agama yang mengajarkan pelajaran agama Hindu adalah orang Hindu yang berasal dari Towani Tolotang. Jenjang kesarjanaannya diselesaikan pada institusi agama Hindu yakni pada Sekolah Tinggi Agama Hindu Negeri (STAHN) yang sekarang berubah nama menjadi Universitas Hindu Dharma (UHD) Bali. Berbeda pada tahun-tahun sebelumnya, pemberian pelajaran agama Hindu di Amparita dipusatkan di Pangkajene. Saat ini, pelajaran agama Hindu langsung diadakan di sekolah. Di SMP 1 Amparita, memang mayoritas siswanya merupakan keturunan Towani Tolotang sehingga pelajaran agama Hindu langsung diberikan di sekolah. Untuk daerah lain, pengajaran pelajaran agama Hindu dilakukan di Tanru Tedong (SMP 1) dan Pangkajene.
Pada persiapan Ujian Akhir Nasional (UAN), siswa-siswi yang berasal dari Towani Tolotang tidak lagi mendapat kesulitan menerima pelajaran agama dalam rangka menghadapi tes/ujian. Ketersediaan guru merupakan faktor yang sangat penting dalam proses pembelajaran. Kehadiran guru yang memiliki kualitas dan kapabilitas yang sesuai dengan tuntutan atau kebutuhan peserta didik akan mempermudah transformasi ilmu dari guru ke peserta didik. Sebelumnya, pelajaran agama Hindu diberikan hanya sekali dalam seminggu dan dilakukan di tempat lain, bukan di sekolah peserta didik sendiri. Saat ini, peserta didik yang berasal dari Towani Tolotang menerima pelajaran yang diampu oleh guru yang memiliki latar berlakang kultural yang sama dengan mereka.

Perhatian negara khususnya Kementerian Pendidikan Nasional dan Kementerian Agama dari aspek pendidikan bagi Towani Tolotang tidak mengalami kendala. Hal ini disebabkan oleh pilihan Towani Tolotang tadi yang telah menjadi bagian agama Hindu. Hal ini juga memperlihatkan bahwa pilihan Towani Tolotang untuk memilih salah satu agama adalah tepat. Segala urusan yang berhubungan dengan administrasi tidak mengalami kendala. Pelayanan publik pun sama dengan pelayanan yang diterima oleh masyarakat umum lainnya. Dengan demikian, Towani Tolotang telah memiliki peluang yang sama dengan penganut agama lain untuk mendapatkan pelayanan dan pemenuhan kepentingan yang lain. Tindakan diskrimasi dari aspek pendidikan tidak ada lagi karena keterpenuhan tenaga pengajar dan kurikulum telah tercapai, hanya saja muatan lokal (ajaran Towani Tolotang) tidak dimasukkan sehingga pewarisan nilai-nilai ketolotangan tidak terjadi di institusi pendidikan seperti di sekolah-sekolah formal.

\section{Variasi Ide dalam Memposisikan Towani Tolotang}

UU Nomor 1/PNPS/1965 tentang Pencegahan Penyalahgunaan dan Penodaan Agama yang memuat tentang pembatasan 
agama di Indonesia merupakan landasan negara melakukan upaya penyeragaman terhadap berbagai kelompok agama di $\mathrm{Nu}$ santara. Upaya tersebut dilakukan mengingat banyaknya agama atau keyakinan yang dianut oleh masyarakat yang tersebar di berbagai tempat. Di seluruh pelosok $\mathrm{Nu}$ santara terdapat beragam agama yang bersifat lokal yang hanya dianut oleh masyarakat setempat. Untuk menyatukan mereka, maka negara pun melakukan upaya penyeragaman melalui upaya 'merger' terhadap agama-agama lokal tersebut ke dalam salah satu agama yang telah diakui.

Pasal 29 ayat 2 UUD 1945 yang sangat jelas menjadi basis konstitusi kebebasan beragama tidak serta-merta dijadikan acuan dalam mengatur agama dan penganutnya. Pasal ini memuat sangat jelas hak yang diberikan kepada siapa pun untuk menjalankan apa yang diyakini. Namun, pada level implementasi seperti pada UU No.1/PNPS/ 1965, justru membatasi kebebasan penganut agama menjalankan keyakinannya. Pengakuan negara terhadap enam agama berdampak pada sulitnya agama-agama lokal mengembangkan diri. Mereka terus berada di bawah bayang-bayang isu penodaan terhadap agama. Mereka pun dengan terpaksa menerima dan mengakui salah satu dari enam agama yang telah mendapat legitimasi negara.

Pengakuan agama lokal terhadap agama resmi terwujud dalam bentuk afiliasi mereka ke dalam salah satu agama. Pilihan tersebut merupakan pilihan yang sulit. Di satu sisi, agama lokal ingin tetap mempertahankan eksistensi ajarannya yang sejak lama dipraktikkan. Di sisi lain, agama lokal berhadapan dengan kebijakan negara yang mengkooptasi hak-hak mereka. Pada kondisi seperti ini, afiliasi atau memilih salah satu agama tentu merupakan pilihan yang dilematis. Agama-agama lokal yang keberadaannya jauh sebelum agama resmi tidak memiliki pilihan lain kecuali bergabung dengan salah satu dari agama-agama tersebut demi keamanan dan keberlangsungan ke depan.
Dalam banyak kasus, agama lokal yang sebelumnya eksis digabungkan ke dalam salah satu agama. Dikatakan 'digabungkan' karena bukan semata keinginan mereka, tetapi keinginan negara melalui kebijakan dengan alasan penyeragaman untuk memudahkan kontrol terhadap agama. Agama lokal di beberapa tempat memilih salah satu agama juga bukan berdasarkan pilihan sendiri, tetapi dipilihkan oleh negara. Negara dengan leluasa mengatur seluruh aspek kehidupan warganya tak terkecuali kehidupan sosial keberagamaan. Akibatnya, agama menjadi bagian yang tak terpisahkan dengan negara.

Towani Tolotang merupakan satu dari sekian banyak agama lokal yang dipilihkan oleh negara ke dalam salah satu agama resmi oleh negara. Pada Keputusan Dirjen Bimas Hindu Bali/Budha No. 2/1966 disebutkan bahwa Towani Tolotang merupakan salah satu sekte agama Hindu. Mengacu pada keputusan hukum tersebut, Towani Tolotang otomatis menjadi bagian agama Hindu. Secara administrasi, segala bentuk urusan berkiblat pada agama Hindu. Penggabungan Towani Tolotang ke dalam agama Hindu didasarkan pada kenyataan bahwa ia memiliki banyak kemiripan praktik keagamaan dengan agama Hindu.

Salah satu kemiripan praktik keagamaan Towani Tolotang dengan agama Hindu adalah persembahan sesajian dalam ritual yang dilakukan. Baik Towani Tolotang maupun Hindu memposisikan sajen pada posisi penting dalam setiap ritual. Seperti yang telah diuraikan sebelumnya, sesajian Towani Tolotang pada pelaksanaan ritual mappenre' nanre merupakan unsur pokok dan penentu karena dianggap sebagai media untuk menyampaikan permintaan kepada Dewata Seuwae. Demikian pula dalam praktik Hindu, sesajian memiliki arti yang sangat penting dalam setiap ritual yang dilakukan.

Formalisasi agama berdampak pada bagaimana agama lokal seperti Towani Tolotang menentukan pilihan agama sebagai induknya. Towani Tolotang, agar tidak dicap sebagai agama sempalan, dipilihkan 
menjadi bagian agama Hindu sebagai agama yang memayunginya. Pilihan tersebut, pada satu sisi membatasi ruang gerak Towani Tolotang untuk mempraktikkan ajaran-ajarannya. Ia harus tunduk di bawah 'arahan' Hindu. Pada sisi lain, pilihan untuk menganut agama Hindu memberikan peluang bagi Towani Tolotang baik ajaran maupun komunitas untuk tetap eksis karena tidak ada lagi ruang untuk mengganggunya karena secara formal telah berada di bawah agama Hindu.

\section{Agamaisasi Towani Tolotang}

Towani Tolotang 'selamat' dari islamisasi pada saat Raja Wajo menginstruksikan seluruh warganya memeluk Islam. Pada saat itu, Towani merespons kebijakan tersebut dengan 'pembangkangan' yang berdampak pada pengusiran mereka dari daerah tempat tinggalnya. Setelah berdiam di Sidenreng Rappang, upaya negara untuk merampingkan agama-agama di Indonesia dilakukan. Hasilnya, hampir seluruh agama lokal yang tersebar di berbagai tempat memilih salah satu agama yang telah ditetapkan oleh negara. Towani Tolotang harus memilih agama Hindu sebagai agama induk dengan segala konsekuensinya.

Afiliasi Towani Tolotang ke dalam agama Hindu terjadi dalam waktu yang cukup lama. Penerimaan terhadap Hindu tidak serta-merta terjadi. Berbagai upaya dilakukan oleh Towani Tolotang untuk tetap pada identitasnya. Pada tahun 1966, H.A. Sapada Mappangile sebagai Bupati Sidenreng Rappang mengeluarkan keputusan yang menegaskan bahwa Towani Tolotang bukan agama (Mudzhar, 2002:192). Akibatnya, segala bentuk praktik keagamaan Towani Tolotang tidak boleh dilakukan. Segala bentuk kegiatan Towani Tolotang pun harus dilaksanakan sesuai dengan ajaran Islam, termasuk upacara kematian dan perkawinan.

Pada tahun yang sama, beberapa tokoh Towani Tolotang mengirim surat keberatan kepada DPR-GR dan MPRS di Jakarta yang berisi tentang adanya oknum pemerintah daerah yang berupaya menghalangi pelak- sanaan upacara keagamaan yang sebelumnya dilakukan. Towani Tolotang pun mengirim surat kepada Ketua Presidium Kabinet Ampera yang mengajukan permohonan perlindungan dari pemaksaan terhadap mereka untuk memeluk Islam. Masih pada tahun 1966, surat Menteri Agama No. B-III/ 3/1356/1966 menyatakan bahwa Towani Tolotang bukan sebuah agama. Surat keputusan ini memperkuat keputusan yang telah dikeluarkan oleh pemerintah daerah Sidenreng Rappang sebelumnya.

Keputusan Menteri agama di atas dikuatkan lagi oleh keputusan Kementerian Kejaksaan No. 152/Sospol-K/Pakem/15 $\mathrm{km} / 1966$ yang berisi tentang perintah terhadap Kejaksaan Tinggi di Makassar untuk membubarkan dan melarang agama Tolotang (Mudzhar, 2002: 194). Melihat kenyataan tesebut, tokoh Towani Tolotang menyatakan untuk sementara waktu mereka bernaung di bawah agama Islam sambil menunggu keputusan dari pemerintah pusat. Pada saat itu, tokoh Towani Tolotang pun menyetujui sekiranya permohonan mereka tidak dikabulkan oleh pemerintah pusat, maka akan tetap berada di bawah agama Islam. Adanya pernyataan dari tokoh Towani Tolotang tersebut mengubah konstalasi politik di Amparita. Kondisi wilayah mulai tenang setelah terjadi perdebatan panjang mengenai status Towani Tolotang.

Pada tahun 1966, berselang beberapa bulan setelah adanya pernyataan penerimaan Islam oleh tokoh Towani Tolotang, Direktur Jenderal Bimbingan Masyarakat Hindu Bali/Budha No. 2/1966 mengeluarkan keputusan susulan yang menyatakan bahwa Towani Tolotang merupakan salah satu sekte agama Hindu dan mengangkat Makkatungeng sebagai pembimbing Towani Tolotang dan melaporkan kepada Bimas Hindu Bali Budha di Jakarta tentang kegiatan Towani Tolotang secara berkala. Ini artinya, Towani Tolotang tidak lagi berada di bawah naungan agama Islam seperti keinginan orang-orang Islam tetapi berada di bawah agama Hindu. 
Pada perkembangan selanjutnya, Dirjen Bimas Hindu Bali Budha mengeluarkan keputusan yang mempertegas keputusan sebelumnya. Bahkan, Kejaksaan Agung RI meminta kepada Bimas Hindu Bali Budha untuk mencabut surat tersebut. Melihat kasus Towani Tolotang tidak menemui titik terang, persoalan keputusan Dirjen Bimas Hindu Bali Budha diambil alih oleh Menteri Agama. Sementara, Panglima Kodam XIV Hasanuddin, mengeluarkan surat keputusan No. Kpe. 010/05/PPD/1967 yang menyatakan bahwa persoalan Towani Tolotang menjadi tanggungjawab KODAM XIV Hasanuddin dan surat keputusan Dirjen Bimas Hindu Bali Budha dinyatakan tidak berlaku di Sulawesi Selatan yang berujung pada Operasi Malilu Sipakainge yang dilancarkan terhadap penganut Towani Tolotang. Operasi tersebut bertujuan untuk meniadakan kegiatan Towani Tolotang.

Uraian di atas menunjukkan adanya dua kepentingan yang berbeda terkait dengan Towani Tolotang. Pemerintah Daerah Sidenreng Rappang yang mewakili masyarakat menginginkan agar Towani Tolotang memeluk Islam. Akan tetapi, pemerintah pusat justru menghendaki Towani Tolotang menjadi bagian agama Hindu. Pada kenyataannya, sampai saat ini, Towani Tolotang masih berada di bawah naungan agama Hindu, bukan agama Islam. Hal ini ditegaskan oleh pengisian Hindu pada kolom Kartu Tanda Penduduk oleh Towani Tolotang. Terlihat pula dengan jelas bahwa Towani Tolotang berada pada bayang islamisasi dan hinduisasi. Hinduisasi tidak hanya terjadi terhadap Towani Tolotang, tetapi juga terhadap beberapa agama lokal di Sulawesi Selatan (Ramstedt, 2004).

\section{SIMPULAN}

Towani Tolotang dalam perjalanannya, dihadapkan pada dua macam bentuk diskriminasi. Diskriminasi yang pertama adalah diskriminasi yang berasal dari negara dengan model yang rapi dalam bentuk regulasi-regulasi yang membatasi ruang gerak Tolotang dalam menjalankan ajaran-ajaran- nya. Terlebih lagi, Towani Tolotang diafiliasikan ke dalam agama Hindu merupakan bentuk paksaan dari pemerintah. Namun, harus pula diakui bahwa diskriminasi seperti ini juga menguntungkan Towani Tolotang. Kedua adalah bentuk diskriminasi yang berasal dari masyarakat di mana Towani Tolotang berada karena tidak semua lapisan masyarakat menghendaki Towani Tolotang untuk tetap eksis. Bentuk-bentuk diskriminasi tersebut bukan hanya dialami oleh Towani Tolotang akan tetapi juga terhadap semua aliran/komunitas keagamaan yang ada di berbagai tempat. Kedua bentuk diskriminasi di atas mencerminkan kontrol pemerintah yang sangat jauh memasuki area privat agama. Ini berdampak pada ketidakleluasaan agama lokal untuk mengembangkan diri dan ketidaksiapan sebagian masyarakat dalam menerima perbedaan khususnya dalam hal perbedaan keyakinan serta ketidakdewasaan dalam beragama.

Agama-agama lokal yang masih eksis hingga saat ini di satu sisi menerima segala bentuk penataan atau konstruk negara terhadapnya. Mereka menganut agama yang ditentukan oleh negara. Dalam persoalan administrasi kependudukan, mereka mencantumkan salah satu agama resmi negara sebagai agama resminya. Namun di sisi lain, mereka juga melakukan perlawanan-perlawanan atau pembangkangan-pembangkangan terhadap segala bentuk penataan dan regulasi negara. Meskipun telah berafiliasi ke dalam dalah satu agama resmi negara, tetapi mereka tetap menjalankan kepercayaan atau ajarannya. Secara struktur, mereka berada di bawah salah satu agama resmi negara, tetapi secara kultur tetap mempraktikkan ajaran-ajarannya. Proyek agamaisasi negara ternyata sangat menguntungkan agama lokal seperti Towani Tolotang.

Tawaran enam agama di satu sisi merupakan pembatasan negara yang sangat jelas terhadap eksistensi agama-agama lokal. Dengan enam agama yang wajib dipilih, berdampak langsung pada konsistensi sikap agama-agama lokal untuk terus bertahan. 
Namun di sisi lain, tawaran seperti ini harus pula dipahami sebagai bentuk tanggungjawab negara terhadap keberlangsungan kehidupan warga negara. Dalam konstitusi sangat jelas digariskan bahwa negara berkewajiban mewujudkan kehidupan yang tertib. Salah satu upaya negara untuk mewujudkan amanah tersebut adalah dengan melakukan penataan-penataan yang bersifat menyeluruh dalam segala sektor termasuk agama meskipun perlu ditinjau kembali untuk memastikan efektivitas penataan ditempuh.

Regulasi-regulasi yang mengatur persoalan agama menjadikan agama lokal khususnya Towani Tolotang sebagai penganut yang memiliki identitas yang tidak terisolasi dengan penganut agama lain. Afiliasi terhadap agama tertentu memantapkan posisinya sebagai agama yang dapat dan mampu menjalankan aktivitas-aktivitas keagamaan di masa depan. Towani Tolotang bukan lagi sebuah komunitas agama yang memiliki pembatasan, tetapi ia telah menjelma sebagai penganut agama yang setara dengan yang lain. Namun demikian, regulasi negara menimbulkan perlawananperlawanan baru di kalangan agama lokal meskipun sangat halus. Hal ini menjadikan Towani Tolotang sebagai agama yang tidak hanya berusaha bertahan, tetapi juga terus dipertahankan oleh kalangan tertentu dengan kepentingan tertentu pula.

Penataan negara terhadap agama merupakan salah satu bentuk diskriminasi yang akan mematikan agama-agama lokal. Oleh karena itu, kebijakan negara tersebut perlu ditinjau kembali untuk memastikan adanya ruang yang cukup bagi agama-agama lokal untuk berkembang. Agama-agama lokal yang sejak dulu eksis merupakan salah satu kekeyaan bangsa yang harus dikelola dengan baik. Pengelolaan tersebut dapat ditempuh melalui regulasi yang tidak memarginalkan mereka. Keberpihakan negara terhadap agama-agama besar yang ada saat ini perlu ditafsir ulang bentuk-bentuk keberpihakannya. Keberpihakan bukan melulu diartikan sebagai bentuk pemberian fasilitas, tetapi justru penghargaan terhadap yang lain.

\section{DAFTAR PUSTAKA}

Hasse J., 2008, “Agama Tolotang di Tengah Dinamika Sosio-Politik Indonesia: Konstruksi Negara atas Komunitas Tolotang di Sulawesi Selatan", dalam Irwan Abdullah (ed.), Agama dan Kearifan Lokal dalam Tantangan Global. Yogyakarta: Sekolah Pascasarjana UGM-Pustaka Pelajar.

Idaman, 2005, "Rirual, Identitas, dan Modernitas: Redefinisi Kepercayaan Aluk Todolo di Tana Toraja Sulawesi Selatan" Tesis. Agama dan Lintas Budaya, Sekolah Pascasarjana UGM, Unpublished.

Kholiludin, T., 2009, Kuasa Negara atas Agama: Politik Pengakuan, Diskursus "Agama Resmi" dan Diskriminasi Hak Sipil. Semarang: RaSAIL.

Ma'arif, S., 2003, 'Religious Freedom in Indonesia the Constitution, Islamization of the Ammatoa of Sulawesi', Tesis. Yogyakarta CRCS-UGM, Unpublished.

Mattulada, 1982, “Manusia dan Kebudayaan Bugis-Makassar", dalam Berita Antropologi, tahun XI, Nomor 38 Juli-September, 1980. Jakarta: Universitas Indonesia.

Mudzhar, A., 2002, Pendekatan Studi Islam dalam Teori dan Praktek. Yogyakarta: Pustaka Pelajar.

Nurudin, (ed.). 2003. Agama Tradisional: Potret Kearifan Hidup Masyarakat Samin dan Tengger. Yogyakarta: LkiS-FISIP Universitas Muhammadiyah Malang.

Qoyim, I., 2004, "Agama dan Pandangan Hidup Masyarakat Towani Tolotang" dalam Ibnu Qoyim (ed.), Religi Lokal dan Pandangan Hidup: Kajian tentang Masyarakat Penganut Religi Tolotang dan Patuntung, Sipelebegu (Permalim), Saminisme, dan Agama Jawa Sunda. Jakarta: Lembaga Ilmu Pengetahuan 
Indonesia Pusat Penelitian Kemasyarakatan dan Kebudayaan (PMB-LIPI).

Ramstedt, M., 2004, Hinduism in Modern Indonesia: A Minority Religion between
Local, National, and Global Interests. London: Routledge Curzon.

Rosyid, M., 2008, Samin Kudus: Bersahaja di Tengah Asketisme Lokal. Yogyakarta: Pustaka Pelajar. 